\title{
Teat anatomy affects requirements for udder preparation in Mediterranean buffaloes
}

\author{
Sarah Ambord ${ }^{1}$, Michael H Stoffel ${ }^{2}$ and Rupert M Bruckmaier ${ }^{1 *}$ \\ ${ }^{1}$ Veterinary Physiology, Vetsuisse Faculty, University of Bern, Bern, Switzerland \\ ${ }^{2}$ Veterinary Anatomy, Vetsuisse Faculty, University of Bern, Bern, Switzerland
}

Received 3 February 2010; accepted for publication 1 July 2010; first published online 8 September 2010

\begin{abstract}
The present study was conducted to assess the interrelation between teat anatomy and machine milking in dairy buffaloes raised in Switzerland. A 3-min pre-stimulation induced milk ejection before cluster attachment in most cases and caused an optimal milk removal during machine milking. In an additional experiment, longitudinal cross-section ultrasound was obtained before and after a 3-min pre-stimulation. Teat wall thickness, teat diameter, cisternal diameter and teat canal length were evaluated. It was observed that 3-min pre-stimulation dramatically reduced teat canal length whereas all the other anatomical parameters remained unchanged. The vacuum needed to open the teat canal was also measured before and after a 3-min pre-stimulation by using a special teat cup with only the mouthpiece of the liner remaining on the top of the teat cup (no liner, no pulsation). Without pre-stimulation but after wetting the teat canal by stripping one squirt of milk out of the teat, no milk could be withdrawn with a vacuum up to $39 \mathrm{kPa}$. However, after pre-stimulation, milk flow occurred in all buffaloes at a vacuum between 16 and $38 \mathrm{kPa}$. In the last experiment, the teat tissue was examined in slaughtered buffaloes and compared with teat tissue of cows. No difference was noted in histological sections and teat canal length was similar in cows and buffaloes. Proximal to the teat canal, the teat did not pass into an open cistern but the lumen was collapsed. In conclusion, buffaloes need to be well prestimulated because the tissue above the teat canal provides additional teat closure before milk ejection. Therefore, milk can only be obtained after pre-stimulation.
\end{abstract}

Keywords: Teat anatomy, buffaloes, machine milking, pre-stimulation.

Water buffaloes contribute considerably to milk production in many countries of Asia and other parts of the world. The milk produced by buffaloes is an important source of high-quality animal protein and energy in many developing countries (Thomas, 2008). Besides, buffaloes have been kept in Italy for centuries to harvest milk for the original buffalo mozzarella cheese (Thomas, 2008). Recently, buffalo milk production has been increasing in other European countries including Switzerland to allow the local production of buffalo dairy products.

Worldwide, and particularly in Europe, machine milking instead of hand milking is increasingly required to reduce exhausting and expensive labour on the one hand, and to increase the hygienic quality of harvested milk on the other hand (Thomas, 2008).

*For correspondence: rupert.bruckmaier@physio.unibe.ch
However, it has been shown that successful machine milking is much more complex in buffaloes than in cows. Thus, it has been demonstrated that a careful udder preparation including pre-milking stimulation is crucial to avoid milking on empty teats for several minutes at the start of milking (Thomas et al. 2005).

In buffaloes, cisternal milk amounts only to about $5 \%$ (Thomas et al. 2004) which is much less than in dairy cows with about $20 \%$ and goats and sheep with $50 \%$ or even more (Bruckmaier \& Blum, 1992, 1998; Rovai et al. 2008; Salama et al. 2004). Cisternal milk in cows, goats and sheep is immediately available for the milking machine (Bruckmaier \& Blum, 1998). In buffaloes, frequently not even the cisternal milk can be removed by machine milking without pre-stimulation and milking on empty teats is the consequence (Thomas, 2004; Ambord et al. 2009). However, the small amount of milk stored in the mammary cistern can be removed by hand milking, i.e. squeezing the milk out of the teat, whereas by the application of the 
milking vacuum, usually no milk can be removed even if the teat canal has been wetted by hand stripping before (Ambord et al. 2009). This phenomenon might be due to extremely long teat canals. When determined by b-mode ultrasound, the teat canal length before pre-stimulation is around $37 \mathrm{~mm}$ in rear teats and $30 \mathrm{~mm}$ in front teats (Thomas et al. 2004). The vacuum needed to open the teat canal in dairy cows is around $20 \mathrm{kPa}$ (Weiss et al. 2004) whereas a vacuum of up to $45 \mathrm{kPa}$ in buffaloes is generally ineffective unless alveolar milk ejection has occurred (Ambord et al. 2009).

As in cows, milk ejection in buffaloes occurs only in response to oxytocin release, which is induced by teat stimulation (Bruckmaier \& Blum, 1996; Bruckmaier, 2005; Thomas et al. 2005). While sufficient teat stimulation is provided by the normal pulsation of the teat cup liner in cows, attachment of the milking machine without pre-stimulation rarely induced oxytocin release and milk ejection in Indian Murrah water buffaloes (Thomas et al. 2005). Similar observations were made in ewes (Bruckmaier et al. 1997).

The objective of the present study was to investigate the reason why buffaloes are much more refractory to machine milking than dairy cows, in particular at the start of milking. Relationships between udder anatomy and milking characteristics were investigated.

\section{Materials and Methods}

\section{Animals and housing}

Buffaloes from two private farms in Switzerland were used for the experiments. On farm 1, 70 lactating buffaloes were kept in a loose housing barn and machine milking was performed in a tandem milking parlour. On farm 2, 15 buffaloes were kept in a tie stall barn and milked with a Happel high line milking machine (System Happel GmbH, 87654 Friesenried, Germany). Experiments 1 and 3 were performed on 9 and 7 animals, respectively, from farm 1, Experiment 2 used 13 animals from both farms, and Experiment 4 was performed on 2 animals from farm 2.

\section{Experiment 1: Pre-milking stimulation and milk removal}

The goal of this experiment was to identify the ideal duration of pre-stimulation to avoid delayed milk ejection during machine milking in both early and late lactation. Out of the 9 experimental buffaloes, 5 were in early lactation at $<100$ days in milk (DIM) and 4 were in late lactation (161-240 DIM). At the time of the experiment, animals were in their first (2), fourth (2), fifth (4) and eighth (1) lactations. The buffaloes were milked in a $2 \times 3$ tandem milking parlour with a low-level pipeline milking system (WestfaliaSurge, GEA WestfaliaSurge Suisse AG, 3063 Ittigen, Switzerland) at a vacuum level of $39 \mathrm{kPa}$, a pulsation rate of $60 \mathrm{cycles} / \mathrm{min}$ and a pulsation ratio of 60 : 40. Milking started in the morning at 6.00 (i.e. $13 \mathrm{~h}$ after previous evening milking) and in the evening at 17.00 (i.e. $11 \mathrm{~h}$ after previous morning milking).

Four different treatments were investigated. Every buffalo was milked with every treatment. The treatments were randomly assigned to each individual buffalo at every experimental milking. Milking was performed either without pre-stimulation $(0 \mathrm{~min})$, or after a 1 -min, 2-min or 3-min pre-stimulation, respectively. Pre-stimulation included cleaning of the teats and the udder with a wet cotton towel and drying of the teats with single-use paper before cluster attachment. When milking was performed without prestimulation $(0 \mathrm{~min})$ the cluster was attached directly without any previous tactile contact with the udder and teats.

During all experimental milkings, the occurrence of delayed milk ejection (DME) and the time until delayed milk ejection (tDME) were observed and evaluated. DME refers to a transiently reduced milk flow, i.e. bimodality (separate removal of cisternal and alveolar milk) or a totally delayed milk flow (if no cisternal milk was present) in the milking claw within the first $30 \mathrm{~s}$ after cluster attachment. tDME (no milk or a transient reduction of milk flow in the milking claw within the first $30 \mathrm{~s}$ after cluster attachment) was determined with a chronometer from the start of milking (cluster attachment) until first milk flow or without milk flow until $30 \mathrm{~s}$.

\section{Experiment 2: Teat ultrasound}

The 13 experimental buffalo cows were in early (8) and late (5) lactation in their first (2), second (2), fourth (2), fifth (4), seventh (1) and eighth (2) lactations. Longitudinal ultrasound cross sections of 22 teats (one teat from 10 animals and 4 teats from 3 animals, respectively) were performed before and immediately after a 3-min manual teat stimulation, respectively. The digital ultrasound imaging was performed by the use of a $5-\mathrm{MHz}$ linear b-mode probe (EchoWave 3.37, tpm, 21339 Lüneburg, Germany). The teat was immersed in a plastic cup filled with hand-warm water and the probe was applied to the outside of the cup by using ultrasound gel as previously described for dairy cows (Weiss et al. 2004). Teat canal length, teat diameter and teat wall thickness (average of both walls as visible on the cross section image) and cisternal diameter $2.5 \mathrm{~cm}$ from the teat tip were evaluated from the recorded cross sections.

\section{Experiment 3: Vacuum to open the teat canal}

In Experiment 3, the 7 buffaloes were in early (2) and mid (5) lactation in their first (1), second (1), third (3), fourth (4) and fifth (1) lactations. Vacuum values required to open the teat canal $(\mathrm{VO})$ were recorded at two evening milkings. As in Experiment 2, a longitudinal cross-section ultrasound image of the left front teat was performed. Subsequently, one squirt of milk was stripped out to wet the teat canal and the $\mathrm{VO}$ was measured using a transparent teat cup with only the mouth piece of the liner remaining on the 
Table 1. Time until delayed milk ejection (tDME) and incidence of delayed milk ejection (DME) after different pre-stimulation times

\begin{tabular}{|c|c|c|c|c|c|}
\hline \multirow[b]{2}{*}{ Parameter } & \multirow[b]{2}{*}{$n$} & \multicolumn{4}{|c|}{ Pre-stimulation, min } \\
\hline & & 0 & 1 & 2 & 3 \\
\hline $\begin{array}{l}\text { DME, \% } \\
\text { tDME, min }\end{array}$ & $\begin{array}{l}9 \\
9\end{array}$ & $\begin{array}{l}88 \cdot 9 \pm 11 \cdot 1^{\mathrm{a}} \\
0 \cdot 93 \pm 0 \cdot 10^{\mathrm{a}}\end{array}$ & $\begin{array}{l}55 \cdot 6 \pm 17 \cdot 6^{\mathrm{ab}} \\
0 \cdot 81 \pm 0 \cdot 27^{\mathrm{ab}}\end{array}$ & $\begin{array}{l}22 \cdot 2 \pm 14 \cdot 7^{\mathrm{bc}} \\
0 \cdot 29 \pm 0 \cdot 10^{\mathrm{bc}}\end{array}$ & $\begin{array}{c}0 \pm 0^{\mathrm{C}} \\
0 \cdot 06 \pm 0 \cdot 04^{\mathrm{c}}\end{array}$ \\
\hline
\end{tabular}

a,b,c values within a row without a common letter are significantly different $(P<0 \cdot 05)$

top of the teat cup (no liner, no pulsation). The vacuum was slowly raised from zero until milk flow started or to a maximum of $39 \mathrm{kPa}$ (Weiss et al. 2004). Immediately after the VO measurement, ultrasound imaging was repeated to ensure that no changes of teat measures had occurred during the experiment. Thereafter, machine milking was performed. At the subsequent evening milking, the same experimental procedure was performed, but ultrasound imaging and VO measurement were performed immediately after a 3-min manual teat stimulation.

\section{Experiment 4: Teat anatomy}

For Experiment 4, two buffaloes from Experiment 2 were used. Animals were slaughtered owing to other reasons (vaginal prolapse and cystitis) than udder health problems. Both animals were in late lactation and one was in its second and one in its seventh lactation. To investigate the type of tissue of buffalo teats, the udders were removed immediately after slaughter. All 8 teats were fixed in $4 \%$ buffered formalin (Dr Grogg Chemie AG, 3066 Stettlen, Switzerland) for $24 \mathrm{~h}$, then dehydrated in an ascending ethanol series and embedded in paraffin wax. Histological slides were stained according to the Goldner trichrome procedure (Stevens et al. 1990). Samples were examined with a Zeiss Axiolmager.Z1 microscope (Carl Zeiss AG, 8714 Feldbach, Switzerland) and compared with histological sections of 7 teats from dairy cows as a control (buffaloes and cows are milked with the same type of milking machines) which were collected at the slaughter house. Teat canal length, teat tissue distribution and teat lumen system were evaluated. Goldner staining was chosen as it allows for easy differentiation between smooth muscle cells and connective tissue.

\section{Mathematical and statistical evaluations}

All data are presented as means and SEM. For the statistical evaluation, Mixed Procedures of SAS (release 8.02) were used. The models contained the treatment (or time point, respectively) and the individual buffalo (or teat, respectively) as the repeated subject. Differences of Is-means were localized by Bonferroni's $t$ test and considered significant if $P<0 \cdot 05$.

Treatment differences with respect to the frequency of occurrence of delayed main flow (DMF) were tested for significance $(P<0 \cdot 05)$ by using a Multtest Procedure of SAS.
None of the interactions included in the model [treatment (or time point, respectively) $v$. parity and treatment (or time point, respectively) v. stage of lactation] was significant.

Pearson's correlation was calculated to show possible relationships of teat canal length, teat wall thicknesses and the cisternal diameter after milk ejection with the vacuum needed to open the teat canal (VO).

\section{Results}

\section{Experiment 1}

DME was most frequent and tDME was longest when prestimulation was omitted and both values decreased with increasing duration of pre-stimulation. After a 3-min prestimulation, DME almost did not occur and the tDME was almost $0.06 \mathrm{~s}$ (Table 1 ).

\section{Experiment 2}

The teat canal length, teat diameter, teat cistern diameter and teat wall thickness before and after a 3-min prestimulation (PS) were compared. The teat canal as seen in ultrasound was significantly longer before than after prestimulation (Table 2; Figs 1 and 2). Teat diameter, cisternal diameter and teat wall did not show any significant differences between the two time points (Table 2).

\section{Experiment 3}

Teat canal length before VO measurement $(23 \cdot 6 \pm 2 \cdot 5 \mathrm{~mm})$ was not significantly different $(P=0.62)$ from the canal length after $\mathrm{VO}$ measurement $(25 \cdot 4 \pm 2 \cdot 4 \mathrm{~mm})$ but teat canals were significantly longer before than after a 3-min prestimulation $(22.6 \pm 2.6 \mathrm{~mm} \quad v$. $12.9 \pm 1.5 \mathrm{~mm})$. Without pre-stimulation, no milk could be withdrawn with a continuously increasing vacuum up to $39 \mathrm{kPa}$. In contrast, after a preceding pre-stimulation, milk flow occurred at vacuum values below $39 \mathrm{kPa}$ in all experimental animals. Milk flow started at $27 \cdot 4 \pm 3 \cdot 2 \mathrm{kPa}$, ranging from 16 to $38 \mathrm{kPa}$. There was no significant correlation between $\mathrm{VO}$ and teat canal length or any other traits describing teat anatomy.

\section{Experiment 4}

Teat canal length was smaller before than after prestimulation in all eight teats from the two buffaloes which 
Table 2. Teat canal length $(\mathrm{mm})$ before and after a 3-min pre-stimulation (PS)

$\begin{array}{llllll}\text { Time point } & n & \begin{array}{l}\text { Teat canal length, } \\ \mathrm{mm}\end{array} & \begin{array}{l}\text { Teat diameter, } \\ \mathrm{mm}\end{array} & \begin{array}{l}\text { Teat cistern, } \\ \mathrm{mm}\end{array} & \begin{array}{l}\text { Teat wall, } \\ \mathrm{mm}\end{array} \\ \text { Before PS } & 13 & 23 \cdot 6 \pm 1 \cdot 1^{\mathrm{a}} & 29 \cdot 2 \pm 0 \cdot 5^{\mathrm{a}} & 3 \cdot 9 \pm 1 \cdot 0^{\mathrm{a}} & 12 \cdot 6 \pm 0 \cdot 5^{\mathrm{a}} \\ \text { After PS } & 13 & 14 \cdot 8 \pm 0 \cdot 7^{\mathrm{b}} & 29 \cdot 6 \pm 0 \cdot 6^{\mathrm{a}} & 8 \cdot 9 \pm 0 \cdot 9^{\mathrm{a}} & 10 \cdot 3 \pm 0 \cdot 4^{\mathrm{a}}\end{array}$

$\mathrm{a}, \mathrm{b}$ values within a column without common letter are significantly different $(P<0 \cdot 05)$

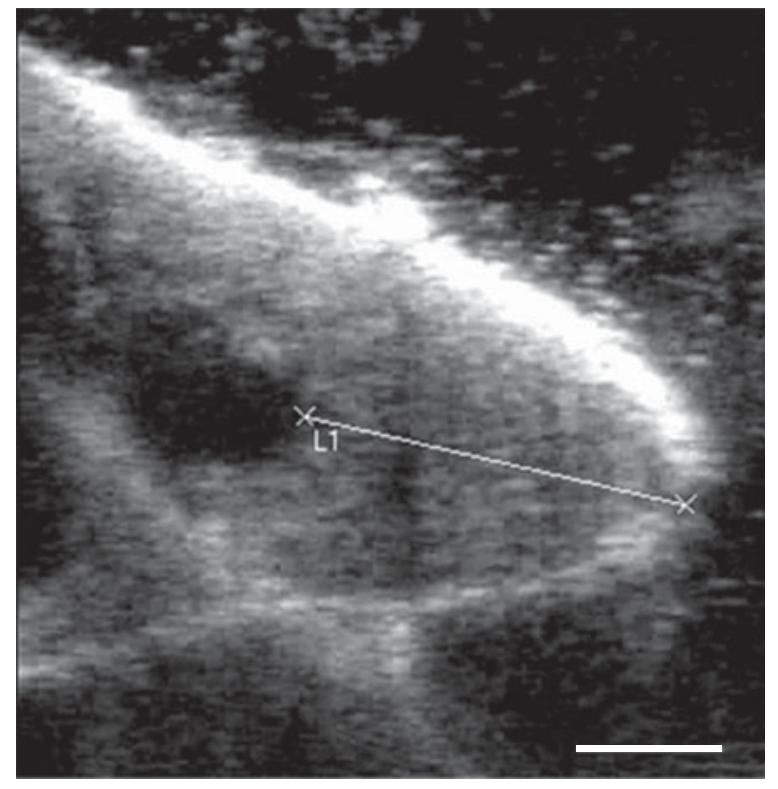

Fig. 1. Ultrasound before pre-stimulation with the assumed teat canal.

were slaughtered the day after the in-vivo measurements. Teat canal was $23 \cdot 9 \pm 2 \cdot 3$ (buffalo 1 ) and $23 \cdot 9 \pm 2 \cdot 4 \mathrm{~mm}$ (buffalo 2) before milk ejection. After milk ejection it was $15 \cdot 6 \pm 1 \cdot 4$ (buffalo 1) and 13.9 \pm 0.9 (buffalo 2) $\mathrm{mm}$. Proximally, the teat canal did not pass into an open cistern as the lumen was collapsed; it seemed that the teat canal was going on (Fig. 3 part 2). Histologically, the difference between the collapsed part and the teat canal was seen in a lower epithelial height of the teat canal. Fig. 3 compared with Fig. 2 shows the collapsed part (2) and the true teat canal (1). On histological sections of dehydrated tissue, teat canal length was $10 \cdot 4 \pm 1 \cdot 0$ (buffalo 1 ) and $9 \cdot 2 \pm 0 \cdot 8 \mathrm{~mm}$ (buffalo 2). Yet, it became apparent on histological sections that the buffalo teats contained about the same amount of smooth muscle cells as was present in 7 randomly obtained teats from lactating dairy cows from the slaughterhouse.

\section{Discussion}

Previous studies addressing machine milking of buffaloes showed that careful teat preparation and pre-stimulation are important preconditions for successful milk removal (Thomas et al. 2005). This finding was confirmed by the

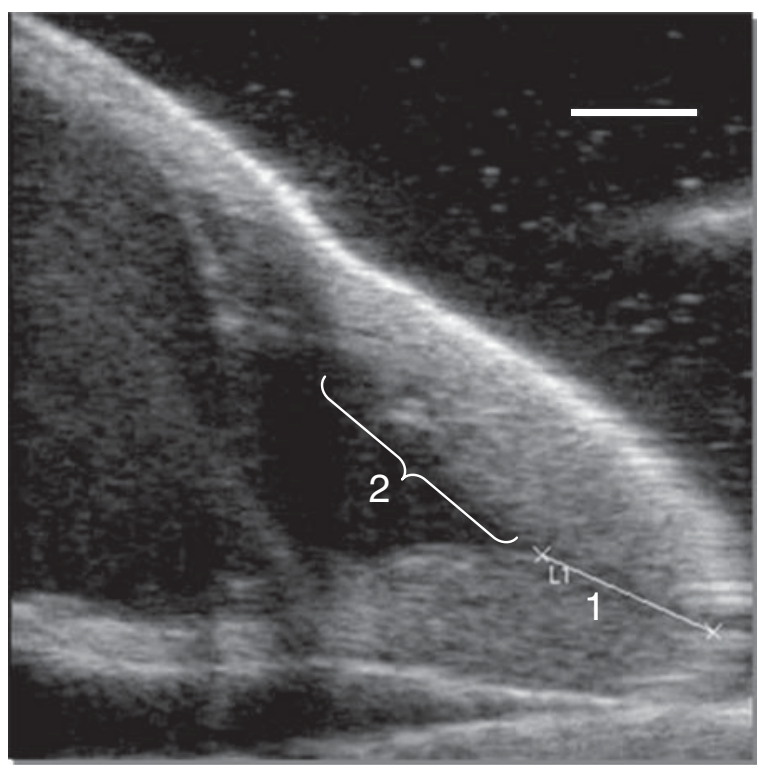

Fig. 2. Ultrasound after a 3-min pre-stimulation with the true teat canal (1) and the collapsing proximal part (2).

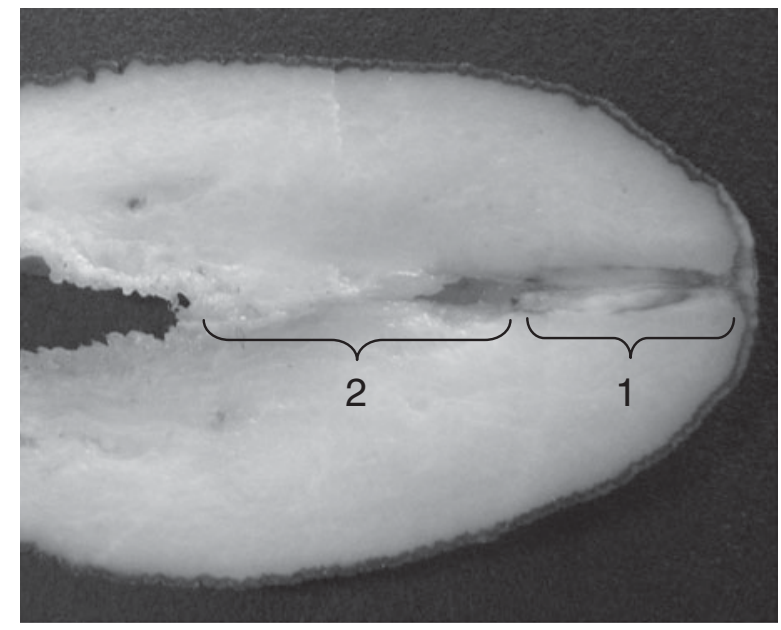

Fig. 3. Formalin-fixed buffalo teat with the true teat canal (1) and the collapsed distal part of the cistern (2).

present investigation, the reasons for this phenomenon being much clearer now. During machine milking, both the frequency of delayed milk ejection and the time until delayed milk ejection decreased with increasing duration of pre-stimulation up to $3 \mathrm{~min}$. After a 3 -min pre-stimulation 
the alveolar milk was obviously ejected in all buffaloes and milk flow occurred immediately after cluster attachment without interruptions until the end of milking. As repeatedly shown in dairy cows, omitting the pre-stimulation causes a transient reduction in milk flow after the cisternal milk is removed (provided there is cisternal milk) and before the milk ejection occurs (Mayer et al. 1984; Bruckmaier \& Blum, 1996; Weiss \& Bruckmaier, 2005). In buffaloes, the amount of cisternal milk is very small (Thomas et al. 2004) and only an extremely small milk fraction is therefore available if milk ejection does not occur before the start of milking. However, even if cisternal milk was present, there was often no visible milk flow prior to milk ejection if the milking cluster was attached and vacuum applied. In contrast, manual pre-stripping allowed the removal of cisternal milk also before milk ejection. That means that the teat canal can be opened if the milk is pressed to the teat canal from inside the udder (hand stripping), but not if a negative pressure is applied from outside (milking machine vacuum). This indicates that the teat closure is much tighter in buffaloes than in dairy cows and its characteristics differ between the two species. In cows, the cisternal milk is always easily obtained by machine milking before milk ejection (Bruckmaier et al. 1994; Weiss et al. 2004) which is basically impossible in buffaloes. By pressing the cisternal milk into the teat by stripping, the teat canal barrier could easily be overcome whereas vacuum application to the teat obviously rather enforced the teat closure. The induction of milk ejection requires tactile stimulation of the teats and/or the udder which causes the release of oxytocin and hence myoepithelial contraction and alveolar milk ejection (Bruckmaier \& Blum, 1996; Bruckmaier, 2005). The latency period of milk ejection in Indian buffaloes in response to exogenous oxytocin is around $25 \mathrm{~s}$ (Thomas et al. 2004), i.e. very similar to the latency period in dairy cows (Bruckmaier et al. 1994). In the present study, the length of the teat closure structure as observed by ultrasound diminished dramatically during a 3-min prestimulation. As confirmed by our anatomical-histological studies, the teat canal was much shorter than the teat closure observed by ultrasound before pre-stimulation, whereas ultrasound cross-sectioning after pre-stimulation showed the real teat canal length, which was only slightly longer than in dairy cows (Weiss et al. 2004). Obviously, the morphology of teat closure changed in response to milk ejection and increased intracisternal pressure during teat stimulation. To investigate whether the length of the teat closure structure has an influence on the vacuum needed to open the teat canal, VO was measured before and after a 3-min pre-stimulation. In cows milk flow starts at a vacuum (VO) $<21 \mathrm{kPa}$ (Weiss et al. 2004). In contrast, in buffaloes milk flow at a vacuum up to $39 \mathrm{kPa}$ did not occur without pre-stimulation but milk flow was observed in all animals after a 3-min pre-stimulation. Thus, the additional teat closure above the teat canal (Fig. 2 and Fig. 3 part 2) prevented milk removal from the cistern by vacuum. In previous studies, this part of teat closure was falsely considered as a part of the teat canal (Thomas et al. 2005) (Fig. 1). Intracisternal pressure rises during milk ejection as demonstrated in cows (Bruckmaier \& Blum, 1996). Obviously, pressure resulting from alveolar milk and smooth muscle tone caused an opening of the additional teat closure structure and only the teat canal remained closed to prevent the milk from leaking. The teat canal could easily be opened by the milking vacuum and milk was obtained as soon as milk ejection had occurred. Teat tissue from slaughtered buffaloes and cows was examined histologically. This provided evidence that the amount of muscle cells in cow and buffalo teats was similar. However, buffalo teats seem to contain qualitatively stronger muscles in the proximal part of the teat directly above the teat canal than cows. Obviously this additional teat closure can be overcome by positive pressure such as pre-stripping, but not by the application of a vacuum to the outer side of the teat.

\section{Conclusion}

Buffalo udders need to be well pre-stimulated before milking because they do not contain much cisternal milk and because the muscle tissue above the teat canal provides additional teat closure before milk ejection. Therefore, milk cannot be obtained before milk ejection by vacuum application but only after milk ejection when the tissue above the teat canal opens.

We thank G Stähli, D Stähli, H Bieri and the Swiss Buffalo Breeders' Federation for their support and patience during the experiments. The outstanding technical assistance of Mrs V Gaschen is gratefully acknowledged.

\section{References}

Ambord S, Thomas CS, Borghese A, Mazzi M, Boselli C \& Bruckmaier RM 2009 Teat anatomy, vacuum to open the teat canal, and fractionized milk composition in Italian buffaloes. Milchwissenschaft 64 351-353

Bruckmaier RM \& Blum JW 1992 B-mode ultrasonography of mammary gland of cows, goats and sheep during $\alpha$ - and $\beta$-adrenergic agonist and oxytocin administration. Journal of Dairy Research 59 151-159

Bruckmaier RM, Rothenanger E \& Blum JW 1994 Measurements of mammary gland cistern size and determination of the cisternal milk fraction in dairy cows. Milchwissenschaft 49 543-546

Bruckmaier RM \& Blum JW 1996 Simultaneous recording of oxytocin release, milk ejection and milk flow during milking of dairy cows with and without prestimulation. Journal of Dairy Research 63 201-208

Bruckmaier RM, Paul G, Mayer H \& Schams D 1997 Machine milking of Ostfresian and Lacaune dairy sheep: udder anatomy, milk ejection and milking characteristics. Journal of Dairy Research 64 163-172

Bruckmaier RM \& Blum JW 1998 Oxytocin release and milk removal in ruminants. Journal of Dairy Science 81 939-949

Bruckmaier RM 2005 Normal and disturbed milk ejection in dairy cows. Domestic Animal Endocrinology 29 268-273 
Mayer H, Schams D, Worstorff H \& Prokopp A 1984 Secretion of oxytocin and milk removal as affected by milking cows with and without manual stimulation. Journal of Endocrinology $\mathbf{1 0 3}$ 355-361

Rovai M, Caja G \& Such X 2008 Evaluation of udder cisterns and effects on milk yield of dairy ewes. Journal of Dairy Science $\mathbf{9 1}$ 4622-4629

Salama AA, Caja G, Such X, Peris S, Sorensen A \& Knight CH 2004 Changes in cisternal udder compartment induced by milking interval in dairy goats milked once or twice daily. Journal of Dairy Science $\mathbf{8 7}$ 1181-1187

Stevens A, Lowe L \& Bancroft JD 1990 Theory and Practice of Histological Techniques New York, USA: Churchill Livingstone

Thomas CS 2004 Milking management of dairy buffaloes Doctoral Thesis, Swedish University of Agricultural Sciences, Uppsala
Thomas CS, Svennersten-Sjaunja K, Bhosrekar MR \& Bruckmaier RM 2004 Mammary cisternal size, cisternal milk and milk ejection in Murrah buffaloes. Journal of Dairy Research 71 162-168

Thomas CS, Bruckmaier RM, Östensson K \& Svennersten-Sjaunja K 2005 Effect of different milking routines on milking-related release of the hormones oxytocin, prolactin and cortisol, and on milk yield and milking performance in Murrah buffaloes. Journal of Dairy Research 72 10-18

Thomas CS 2008 Efficient dairy buffalo production Handbook, DeLaval International $A B$, Tumba, Sweden

Weiss D, Weinfurtner M \& Bruckmaier RM 2004 Teat anatomy and its relationship with quarter and udder milk flow characteristics in dairy cows. Journal of Dairy Science 87 3280-3289

Weiss D \& Bruckmaier RM 2005 Optimization of individual prestimulation in dairy cows. Journal of Dairy Science 88 137-147 